\title{
AKRUAL
}

Jurnal Akuntansi

http://fe.unesa.ac.id/ojs/index.php/akrl

\section{PENGARUH KARAKTERISTIK USAHA WAJIB PAJAK BADAN \\ TERHADAP TINGKAT KEPATUHAN BERDASARKAN PENGUKURAN REPORTING COMPLIANCE (STUDI PADA KANTOR PELAYANAN PAJAK PRATAMA SURABAYA SAWAHAN)}

\author{
Umy Anisari Khulsum \\ Mahasiswa Jurusan Akuntansi Fakultas Ekonomi Universitas Negeri Surabaya \\ Email: umy.anisari@gmail.com \\ Made Dudy Satyawan \\ Jurusan Akuntansi Fakultas Ekonomi Universitas Negeri Surabaya \\ Email: dude05_jr@yahoo.com
}

Artikel diterima: 11 Mei 2014

Terakhir direvisi: 22 Juli 2014

\begin{abstract}
Tax is important source of state revenue for national development. One factor affecting tax revenue increase is tax payer compliance. Self assessment system that applied in Indonesia enable tax payer makes reporting non-compliance. Based on previous research conducted before tax reform 2007, many factors influence taxpayer compliance, one of them is characteristic of business. This study aims to determine the influence of business characteristics corporate tax payer toward level of compliance based on reporting compliance measurement after tax reform 2007. Characteristics of business corporate tax payers in this study include market orientation and business structure. This research method is quantitative. This study was conducted on the tax payer that registered in KPP Pratama Surabaya Sawahan. The analysis technique used is multiple linear regression. The results showed that variable market orientation affect level of compliance based on reporting compliance measurement. But, variables business structure does not affect level of compliance based on reporting compliance measurements.
\end{abstract}

Keywords: Characteristics of Business, Taxpayer Enterprises, Reporting Compliance

\section{PENDAHULUAN}

Pajak merupakan salah satu sumber penerimaan negara yang sangat penting bagi pembangunan nasional. Setiap tahun anggaran (APBN), pemerintah senantiasa berusaha untuk meningkatkan penerimaan pajak guna membiayai pembangunan yang akan dilaksanakan. Oleh karena itu, DJP melakukan restrukturisasi organisasi untuk meningkatkan kesadaran Wajib Pajak agar lebih taat membayar pajak, karena sistem yang baru lebih memungkinkan pembayaran pajak untuk menekan compliance cost. Tax reform 2007 yang mulai efektif tahun 
2008 membuat sistem perpajakan lebih mengandung fairness dibandingkan perundangan sebelumnya (Purnomo, 2004).

Dalam hal ini upaya peningkatan penerimaan pajak dikaitkan dengan kepatuhan wajib pajak (Waluyo, 2010). Kepatuhan pembayaran pajak sangat terkait dengan sistem self assessment yang diterapkan di Indonesia. Keputusan tentang berapa yang akan dilaporkan sangat tergantung dengan keputusan individu dari pembayar pajak, tidak mungkin mengharapkan kepatuhan pajak seratus persen karena berdasarkan risk aversion theory membayar pajak bukanlah sesuatu yang menyenangkan (Allingham dan Sandmo, 1972). Membayar pajak bagaimanapun juga merupakan beban ekonomi bagi pembayarnya yang akan mengurangi tingkat penghasilannya. Fenomena yang terjadi, perilaku penghindaran pajak cenderung menjadi bagian dari perilaku warga masyarakat dalam melakukan pemenuhan tindakan kewajiban perpajakannya. Di sisi lain, dunia usaha bisnis ditujukan untuk memperoleh laba yang besar. Adanya pilihan tarif pajak yang dikenai fasilitas $(50 \%)$ tentu memberikan peluang bagi wajib pajak untuk memilih tarif, karena wajib pajak dapat menyesuaikan penghasilan usahanya untuk terhindar dari pengenaan tarif yang tinggi. Selain itu terdapat perbedaan antara laporan keuangan komersial dan fiskal yang mensyaratkan adanya rekonsiliasi laporan keuangan fiskal. Prinsip bisnis yang mengutamakan keuntungan dapat mendorong perilaku rekayasa penghasilan secara tidak benar.

Indonesia sebagai salah satu negara yang menganut sistem self assessment tidak dapat lepas dari masalah ketidakpatuhan pajak. Dengan tingkat pengawasan yang rendah, yang diindikasi dengan rasio kantor pajak terhadap jumlah Wajib Pajak dimana satu kantor pajak mengawasi rata-rata 20.000 Wajib Pajak, sehingga tingkat ketidakpatuhan pasti lebih tinggi dibandingkan negara maju (Suplemen Pajak, 2013). Oleh karena itu dalam penerapan sistem self assessment terdapat tindakan pengawasan melalui pemeriksaan pajak oleh fiskus. Dari hasil pemeriksaan pajak tersebut, dapat diketahui tingkat kepatuhan Wajib Pajak berdasarkan pengukuran Reporting Compliance (Kepatuhan Pelaporan). Pengukuran tersebut digunakan Internal Revenue Service (US's IRS) dalam The National Research Program (2000) yaitu program yang ditujukan untuk mengetahui tax gap atau tingkat kepatuhan pembayar pajak di Amerika Serikat. Di Indonesia pengukuran tersebut sama halnya dengan tujuan pemeriksaan menurut PMK No.17/PMK.03/2013 yaitu sebagai alat untuk menguji dan meningkatkan kepatuhan, serta sebagai alat ukur untuk mengetahui tingkat kepatuhan Wajib Pajak.

Terdapat banyak faktor yang mempengaruhi tingkat kepatuhan Wajib Pajak dalam konteks bisnis. Selain itu, menurut Suryadi (dalam Hani dan Lubis, 2010) wajib pajak besar lebih tinggi tingkat kesadaran perpajakan dibandingkan dengan wajib pajak kecil. Menurut OECD (Organization for Economic Cooperation and Development, 2004) karakteristik usaha yang dapat mempengaruhi tingkat kepatuhan meliputi bentuk perusahaan, orientasi pasar, data keuangan, umur perusahaan, jenis industri, wilayah, ukuran perusahaan, segmentasi, laba perusahaan, struktur biaya, serta regulasi perusahaan terkait sarana prasarana, pesaing, dan karyawan. Penelitian ini dilakukan setelah tax reform 2007, karakteristik usaha dalam penelitian ini meliputi orientasi pasar, dan bentuk perusahaan. Menurut Chan dan Mo (2002) perusahaan yang sebagian 
besar orientasi pasarnya ke luar negeri (ekspor) cenderung lebih patuh dalam pelaporan peredaran brutonya. Sedangkan perusahaan yang berorientasi dalam negeri (domestic) memiliki perbedaan lebih besar antara hasil pemeriksaan fiskus dengan yang dilaporkan Wajib Pajak.

Bentuk perusahaan antara Perseroan Terbatas (PT) dan non PT memiliki sifat yang berbeda. Contohnya antara PT dan CV, memiliki tingkat kerumitan usaha, derajat keterlibatan pemilik, dan pertanggungjawaban manajemen yang berbeda. Pada bentuk perusahaan persekutuan komanditer, manajemen seharihari biasanya dilakukan oleh pemilik sendiri atau orang kepercayaan dari pemilik itu sendiri. Sedangkan bentuk perusahaan PT pada umumnya memiliki pertanggungjawaban yang ketat pada stakeholders sehingga manajemen lebih sulit jika melakukan rekayasa pembukuan dan laporan keuangan tanpa adanya persetujuan atau sepengetahuan langsung dari stakeholders-nya. Oleh karena itu, bentuk perusahaan PT memiliki tingkat kepatuhan yang lebih tinggi jika dibandingkan dengan perusahaan yang berbentuk perusahaan selain PT (Segara, 2006).

Penelitian Allingham dan Sandmo (1972) membuktikan bahwa pengawasan melalui pemeriksaan mempengaruhi tingkat kepatuhan. Namun demikian seberapa besar pengaruhnya sangat tergantung dari kualitas pemeriksaan itu sendiri. Salah satu yang memengaruhi kualitas pemeriksaan pajak adalah kebijakan pemeriksaan. Di Indonesia penelitian yang menggunakan data audit pajak yang dimiliki Direktorat Jenderal Pajak merupakan hal baru karena sistem administrasi perpajakan yang masih memiliki kekurangan dan sulitnya memperoleh akses terhadap data hasil pemeriksaan. Padahal, tingkat kepatuhan dapat dipengaruhi oleh karakteristik usaha (Chan dan Mo, 2002) sehingga program pemeriksaan harus disesuaikan dengan kondisi tersebut.

Dalam rangka sebagai referensi agar fokus kebijakan perpajakan dapat lebih terarah serta efektif dan efisien, dapat dicapai dengan mengetahui peta kepatuhan Wajib Pajak Badan dikaitkan dengan karakteristik usaha, maka peneliti tertarik untuk melakukan penelitian dengan judul: "Pengaruh Karakteristik Usaha Wajib Pajak Badan Terhadap Tingkat Kepatuhan Berdasarkan Pengukuran Reporting Compliance (Studi pada Kantor Pelayanan Pajak Pratama Surabaya Sawahan)."

\section{KAJIAN PUSTAKA}

Teori dalam penelitian ini adalah Risk Aversion Theory (Teori Risiko Menentang). Teori standar tentang tax compliance ini pertama kali dikemukakan oleh Allingham and Sandmo (1972). Teori ini mengemukakan bahwa tidak ada individu bersedia membayar pajak secara sukarela (voluntary compliance), individu akan selalu menentang untuk membayar pajak (risk aversion). Berdasarkan teori ini, besarnya pendapatan yang dilaporkan (Declared Income) pada SPT Wajib Pajak dipengaruhi kepatuhan wajib pajak. Declared Income bergantung pada perilaku individu terhadap risiko. Perilaku pengambilan keputusan oleh organisasi menentukan sejauh mana tingkat kemungkinan kecurangan dapat terdeteksi (probability of detection), dan seringkali bersifat subyektif. Dalam hal ini perusahaan akan memilih declared income untuk 
memaksimalkan utilitas yang diharapkannya atas tindakan spekulasi dari penghindarannya (evasion gamble).

Penggunaan teori lainnya adalah Teori Organisasi: Besaran (Size) Organisasi dan Teori Akuntansi Positif. Teori Organisasi: Besaran (Size) Organisasi dikemukakan pertama kali oleh kelompok Aston. Teori besaran organisasi merupakan pembahasan mengenai besar kecilnya organisasi, serta apa dan bagaimana dampaknya terhadap pengelolaan organisasi. Organisasi yang lebih besar akan mempunyai lebih banyak peraturan yang bersifat formal. Berdasarkan Teori Akuntansi Positif (Watts dan Zimmerman, 1986) manajemen memilih prosedur akuntansi yang optimal dan mempunyai tujuan tertentu. Perusahaan yang lebih besar akan lebih sensitif terhadap biaya pajak dan menggunakan metode akuntansi yang mengurangi laba bersih laporan keuangan.

\section{Pengertian Pajak}

Menurut Undang-Undang No. 28 Tahun 2007, pajak adalah kontribusi wajib kepada negara yang terutang oleh orang pribadi atau badan yang bersifat memaksa berdasarkan Undang-Undang, dengan tidak mendapatkan imbalan secara langsung dan digunakan untuk keperluan negara bagi sebesar-besarnya kemakmuran rakyat.

\section{Sistem Self Assessment}

Berdasarkan penjelasan pada UU No. 16 Tahun 2000 tentang Perubahan Kedua atas UU Nomor 6 Tahun 1983 Tentang Ketentuan Umum dan Tata Cara Perpajakan, dikatakan bahwa anggota masyarakat Wajib Pajak diberi kepercayaan untuk dapat melaksanakan kegotongroyongan nasional melalui sistem menghitung, memperhitungkan, membayar dan melaporkan sendiri pajak yang terutang (self assessment), sehingga melalui sistem ini administrasi perpajakan diharapkan dapat dilaksanakan dengan lebih rapi, terkendali, sederhana dan mudah untuk dipahami oleh anggota masyarakat Wajib Pajak.

\section{Kepatuhan dan Pengukuran Tingkat Kepatuhan Perpajakan}

Menurut Simon (2003) dalam Gunadi (2005), pengertian kepatuhan pajak (tax compliance) adalah bahwa wajib pajak mempunyai kesediaan untuk mematuhi kewajiban pajaknya sesuai aturan yang berlaku tanpa perlu diadakannya pemeriksaan, investigasi seksama (obtrusive investigation), peringatan atau pun ancaman dan penerapan sanksi baik hukum maupun administrasi. Secara sederhana menurut James and Alley (1999) kepatuhan wajib pajak adalah sekedar menyangkut sejauh mana wajib pajak memenuhi kewajiban perpajakannya sesuai dengan aturan perpajakan yang berlaku. Dengan demikian derajat atau tingkat kepatuhan dapat diukur dengan adanya tax gap, yaitu perbedaan antara apa yang tersurat dalam aturan perpajakan dengan apa yang dilaksanakan oleh seorang wajib pajak.

Secara umum, bentuk-bentuk dari ketidakpatuhan pajak adalah sebagai berikut (Kasipillai and H. A. Jabbar, 2006): Tidak menyampaikan Surat Pemberitahuan Tahunan dalam jangka waktu yang telah ditetapkan, memperkecil (understatement) pendapatan/penghasilan, memperbesar (overstatement) beban, dan tidak membayar pajak terutang tepat waktu.

Internal Revenue Service (Brown dan Mazur, 2003) mengukur tingkat 
kepatuhan pajak dengan tiga pengukuran sebagai berikut:

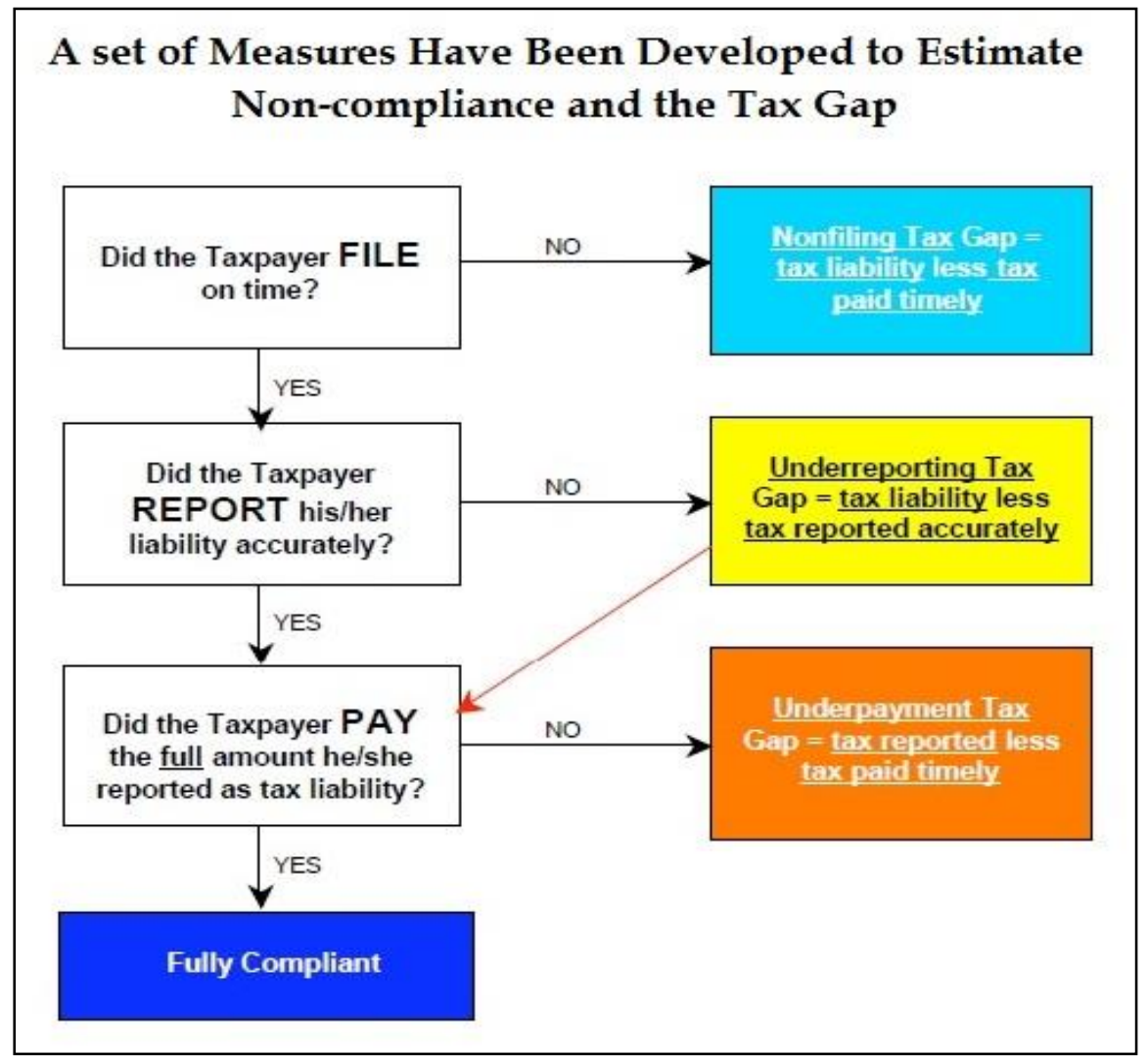

Sumber : Internal Revenue Service (IRS) dalam National Research Program

\section{Gambar 1. Pengukuran Tingkat Kepatuhan Perpajakan}

a. Kepatuhan Penyerahan SPT (Filing Compliance). Kepatuhan dalam penyerahan SPT ini berdasarkan pada ketepatan waktu penyampaian SPT, dimana waktu penyampaian SPT tidak melebihi dari ketentuan yang sudah ditentukan kantor pajak.

b. Kepatuhan Pembayaran (Payment Compliance). Kepatuhan dalam pembayaran didasarkan atas ketepatan dalam nilai dan besaran pajak yang harus dibayar, serta ketepatan waktu pembayarannya.

c. Kepatuhan Pelaporan (Reporting Compliance). Kepatuhan dalam pelaporan berdasarkan pada ketepatan dalam pelaporan nilai pajak yang harus dibayarkan ke kantor pajak. Pendekatan ini mengukur tingkat kepatuhan berdasarkan nominal pajak yang dilaporkan wajib pajak dibandingkan nominal pajak yang seharusnya dilaporkan. Nominal pajak yang seharusnya dilaporkan dapat diketahui melalui hasil pemeriksaan fiskus. Menurut pasal 2 PMK RI No.17/PMK.03/2013, tujuan pemeriksaan adalah menguji kepatuhan pemenuhan kewajiban perpajakan, hal ini sama halnya dengan pengukuran reporting compliance menurut Internal Revenue Service (IRS) dimana membandingkan antara laporan wajib pajak dengan hasil pemeriksaan fiksus untuk mengetahui tingkat kepatuhan wajib pajak. 


\section{Karakteristik Usaha}

OECD (Organization for Economic Cooperation and Development, 2004) dalam kajiannya membuat batasan secara terperinci faktor-faktor yang mempengaruhi kepatuhan dalam konteks bisnis. Berikut ini gambaran faktorfaktor yang mempengaruhi kepatuhan dalam konteks bisnis:

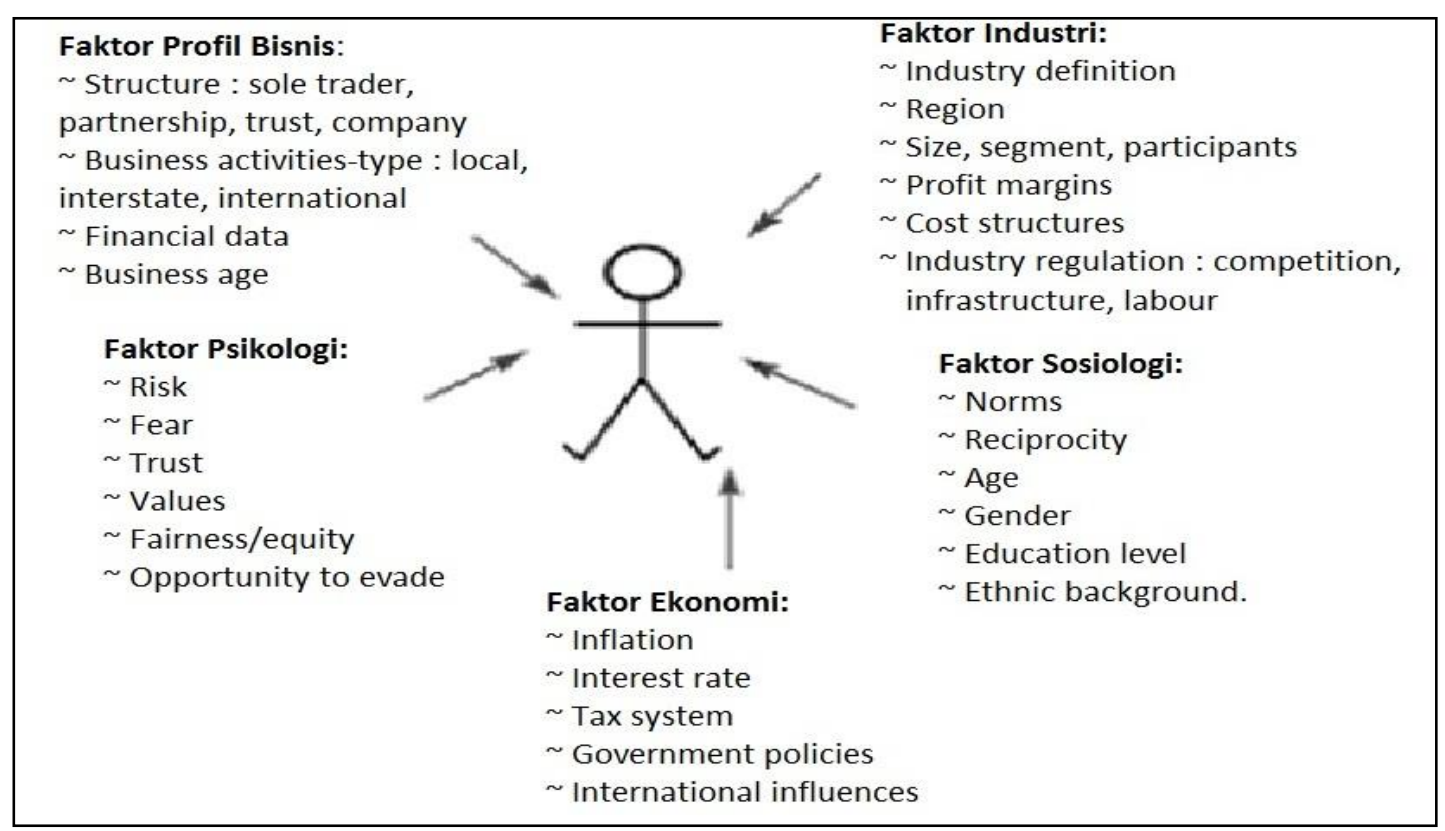

Sumber : Data diolah berdasarkan OECD, 2004

\section{Gambar 2. Faktor-Faktor yang Mempengaruhi Kepatuhan Pajak}

Karakteristik usaha dalam penelitian ini meliputi: (1) Orientasi Pasar, merupakan sasaran utama dari pasar yang dituju dalam penjualan barang dagang yaitu tujuan ekspor atau domestik. Perusahaan berorientasi pasar domestic (dalam negeri) merupakan perusahaan yang hanya menjual produknya di negara domisilinya. Export-oriented firm merupakan perusahaan yang menjual barang sebagian besar di luar negara domisilinya (Fry et al, 2001 dalam Segara, 2006). Perusahaan yang sebagian besar orientasi pasarnya ke luar negeri (ekspor) cenderung lebih patuh dalam pelaporan peredaran brutonya, sedangkan perusahaan yang berorientasi dalam negeri (domestic) memiliki perbedaan lebih besar antara hasil pemeriksaan fiskus dengan yang dilaporkan Wajib Pajak (Chan dan Mo, 2002). (2) Bentuk Perusahaan, merupakan ketentuan hukum yang diacu dalam pendirian badan usaha. Perseroan Terbatas didirikan dengan UU No. 1 Tahun 1995 tentang Perseroan Terbatas, atau dengan peraturan perundangundangan terbaru yaitu UU No.40 Tahun 2007. Jika didirikan selain dengan UU tersebut maka badan tersebut termasuk kategori selain PT. Bentuk perusahaan PT (Perseroan Terbatas) pada umumnya memiliki pertanggungjawaban yang lebih ketat kepada stakeholders dibandingkan dengan perusahaan selain PT (CV. Firma, dll), sehingga manajemen lebih sulit jika melakukan rekayasa pembukuan dan 
laporan keuangan tanpa adanya persetujuan atau sepengetahuan langsung dari stakeholders-nya. Oleh karena itu, bentuk perusahaan PT memiliki tingkat kepatuhan yang lebih tinggi jika dibandingkan dengan perusahaan yang berbentuk perusahaan selain PT (Segara, 2006). meliputi:

Berdasarkan landasan teori di atas, maka hipotesis dalam penelitian ini

Hipotesis 1: Orientasi Pasar berpengaruh terhadap tingkat kepatuhan Wajib Pajak Badan berdasarkan pengukuran reporting compliance;

Hipotesis 2: Bentuk Perusahaan berpengaruh terhadap tingkat kepatuhan Wajib Pajak Badan berdasarkan pengukuran reporting compliance.

\section{METODE PENELITIAN}

\section{Jenis Penelitian}

Jenis penelitian ini adalah kuantitatif. Data yang digunakan dalam penelitian ini adalah data sekunder, yaitu berupa catatan-catatan yang tertuang dalam Laporan Hasil Pemeriksaan Pajak (LHPP), dan Buku Pengawasan Pemeriksaan yang mengadministrasi tentang data pemeriksaan di KPP Pratama Surabaya Sawahan.

\section{Populasi dan Sampel}

Populasi dalam penelitian ini adalah 2.310 Wajib Pajak Badan yang melaporkan SPT. Teknik pengambilan sampel menggunakan purposive sampling. Berdasarkan maksud dan tujuan penelitian, kriteria pemilihan sampel sebagai berikut:

a. Dilakukan pemeriksaan oleh KPP Pratama Surabaya Sawahan atas SPT yang dilaporkan Wajib Pajak Badan setelah diberlakukannya tarif PPh Badan 25\%

b. Proses pemeriksaan KPP telah selesai dilakukan per tanggal 3 Februari 2015

c. Hasil pemeriksaannya menghasilkan produk hukum berupa SKP. Bukan hasil pemeriksaan yang tidak menghasilkan produk hukum berupa SKP (Surat Ketetapan Pajak) dikarenakan pemeriksaan dibatalkan, dialihkan, Wajib Pajak tidak ditemukan, dan karena kebijakan lain.

d. Pada hasil pemeriksaan ditemukan underreporting atau kurang dilaporkannya atas penghasilan neto perusahaan

Berdasarkan kriteria tersebut, jumlah sampel yang diambil dalam penelitian ini adalah 35 Wajib Pajak Badan.

\section{Teknik Analisis Data}

Untuk pengujian hipotesis, digunakan analisis regresi linier berganda karena digunakan untuk memprediksi naik turunnya variabel dependen bila variabel independen sebagai faktor prediktor dimanipulasi (dinaikkan atau diturunkan nilainya). Analisis ini digunakan untuk memperkirakan perubahan variabel tingkat kepatuhan wajib pajak badan apabila variabel Orientasi Pasar dan Bentuk Perusahaan mengalami perubahan.

Variabel dalam penelitian ini meliputi:

1. Variabel Independen, merupakan variabel yang mempengaruhi terhadap variabel yang akan diteliti. Variabel pada masing-masing karakteristik usaha memiliki dua kategori. Setiap kategori berpotensi mempengaruhi tingkat 
kepatuhan Wajib Pajak Badan dalam pemenuhan pajak penghasilan. Variabel independen dalam penelitian ini adalah orientasi pasar (X1) dan bentuk perusahaaan (X2). Pengukuran Orientasi Pasar dalam penelitian ini adalah menggunakan dummy variabel yaitu:

a. Nilai 0 jika Wajib Pajak berorientasi pasar ekspor, yaitu jika komposisi penjualan ekspor sebagian besar atau lebih dari 50\% dari total penjualan.

b. Nilai 1 jika Wajib Pajak berorientasi pasar domestik, yaitu jika komposisi penjualan dalam negeri sebagian besar atau lebih dari $50 \%$ dari total penjualan.

Sedangkan Pengukuran Bentuk Perusahaan dalam penelitian ini adalah menggunakan dummy variabel yaitu :

a. Nilai 0 jika Wajib Pajak Badan termasuk Perseroan Terbatas (PT). Dalam LPP biasanya bentuk perusahaan ditulis langsung setelah nama perusahaan (Misalnya: PT. ABC)

b. Nilai 1 jika Wajib Pajak Badan selain PT, yaitu badan hukum yang didirikan dengan Kitab Undang-Undang Hukum Perdata seperti Persekutuan Komanditer (CV), Firma, koperasi dan badan lainnya. Dalam LPP biasanya bentuk perusahaan ditulis langsung setelah nama perusahaan (Misalnya: CV. Carita).

2. Variabel Dependen, adalah variabel yang dipengaruhi oleh variabel lain. Dalam penelitian ini variabel dependen adalah tingkat kepatuhan wajib pajak badan. Bentuk kepatuhan yang ingin diteliti dalam penelitian ini adalah sebagaimana didefinisikan oleh IRS melalui The National Research Program (NRP) yaitu bentuk kepatuhan pelaporan (Brown, Mazur: 2003). Pengukuran variabel dependen dalam penelitian ini adalah:

$\log 10\left(\frac{\text { Penghasilan neto hasil pemeriksaan }- \text { Penghasilan neto menurut laporan WP }}{\text { Peredaran Bruto }}\right)$

Pengukuran variabel dependen menggunakan koreksi pemeriksaan pajak, dimana semakin tinggi persentase koreksi semakin tidak patuh wajib pajak, sehingga pengukuran variabel dependen dalam penelitian ini mencerminkan tingkat ketidakpatuhan. Semakin besar nilai variabel dependen menunjukkan koreksi pemeriksaan pajak yang semakin besar, berarti bahwa semakin tingginya tingkat ketidakpatuhan. Variabel independen dalam penelitian ini adalah variabel dummy, dimana jika variabel independen berpengaruh positif terhadap tingkat ketidakpatuhan, maka variabel independen tersebut juga berpengaruh negatif terhadap tingkat kepatuhan. Jika salah satu kategori dari variabel dummy dinyatakan memiliki tingkat ketidakpatuhan yang lebih tinggi, sebaliknya kategori pembandingnya memiliki tingkat kepatuhan yang lebih tinggi.

Pembagian selisih koreksi pemeriksaan fiskus dengan peredaran bruto dimaksudkan untuk menghilangkan pengaruh besarnya omset (peredaran bruto) terhadap koreksi yang dihasilkan. Selain itu, persentase koreksi pemeriksaan ditransform ke dalam bentuk logaritma sepuluh untuk mengurangi penyimpangan terhadap asumsi normalitas. Semakin tidak patuh Wajib Pajak, maka nilai logaritma semakin besar. Pengukuran ini sama dengan penelitian Chan dan Mo (2002) pada The Journal of the American Taxation Association dalam penelitian 
di China. Metode pengukuran tersebut juga telah digunakan oleh IRS tahun 2000 pada The National Research Program.

\section{HASIL DAN PEMBAHASAN}

Peneliti mendapatkan sampel data hasil pemeriksaan pada 35 Wajib Pajak Badan yang terdapat selisih kurang atas pelaporan penghasilan neto (Underreporting).

\section{Uji Asumsi Klasik}

\section{a. Uji Normalitas}

Tabel 1. Uji Normalitas

\begin{tabular}{|l|l|r|}
\hline \multicolumn{2}{|c|}{ One-Sample Kolmogorov-Smirnov Test } \\
\hline \multicolumn{2}{|c|}{} & \multicolumn{1}{c|}{ Unstandardized Residual } \\
\hline $\mathrm{N}$ & Mean &, 0000000 \\
\cline { 2 - 4 } Normal Parameters ${ }^{\mathrm{a}, \mathrm{b}}$ & Std. Deviation &, 90726930 \\
\hline \multirow{3}{*}{ Most Extreme Differences } & Absolute &, 106 \\
\cline { 2 - 4 } & Positive &, 106 \\
\cline { 2 - 3 } & Negative &,- 067 \\
\hline Kolmogorov-Smirnov Z &, 625 \\
\hline Asymp. Sig. (2-tailed) &, 829 \\
\hline a. Test distribution is Normal. & \\
\hline b. Calculated from data. & \\
\hline
\end{tabular}

Sumber: Data olah SPSS

Berdasarkan uji normalitas di atas, nilai signifikansi sebesar 0,829 artinya nilai signifikansi di atas 0,05 maka data berdistribusi normal untuk uji variabel (X) terhadap variabel $(\mathrm{Y})$.

\section{b. Uji Autokorelasi}

Uji autokorelasi bertujuan menguji apakah model regresi linier ada korelasi antara kesalahan pengganggu pada periode $\mathrm{t}$ dengan kesalahan pengganggu pada periode sebelumnya $(\mathrm{t}-1)$. Data dalam penelitian ini berbedabeda wajib pajak badan dan tidak menggunakan data time series karena mengamati karakteristik masing-masing Wajib Pajak Badan. Uji autokorelasi dipakai apabila banyaknya data time series minimal yang dapat dihitung dengan Durbin Watson adalah enam buah data dengan satu variabel (Gujarati, 1995), sehingga uji autokorelasi dalam penelitian ini tidak dilakukan karena data yang dipakai dalam penelitian ini tidak dipengaruhi oleh data sebelumnya.

\section{c. Uji Multikolonieritas}

\section{Tabel 2 Uji Multikolonieritas}

\begin{tabular}{lccl}
\hline \multicolumn{1}{c}{ Model } & \multicolumn{2}{c}{ Collinearity Statistics } & \multirow{2}{*}{ Keterangan } \\
\cline { 2 - 4 } & Tolerance & VIF & \\
(Constant) & & & \\
X1 &, 999 & 1,001 & Bebas Multikolinearitas \\
X2 &, 999 & 1,001 & Bebas Multikolinearitas \\
\hline Sumber: Data olah SPSS & & &
\end{tabular}


Jika nilai tolerance $>0,10$ dan nilai VIF $<10$ maka tidak terdapat multikolinearitas. Berdasarkan tabel di atas, hasil uji multikolinearitas pada penelitian ini yaitu tidak terjadi masalah multikolinearitas.

\section{d. Uji Heteroskedastisitas}

Tabel 3 Uji Heteroskedastisitas

\begin{tabular}{llrrr}
\hline & Model & T & Sig. & Keterangan \\
1 & (Constant) & $-1,135$ &, 265 & \\
\hline X1 &, 567 &, 575 & Tidak terjadi heterokedastisitas \\
& X2 & $-1,155$ &, 257 & Tidak terjadi heterokedastisitas \\
\hline
\end{tabular}

Sumber: Data olah SPSS

Hasil tampilan output SPSS di atas menunjukkan bahwa koefisien parameter untuk variabel independen tidak ada yang signifikan, maka dapat disimpulkan bahwa model regresi tidak terdapat Heteroskedastisitas.

\section{Koefisien Determinasi}

Tabel 4 Koefisien determinasi $\left(\mathbf{R}^{2}\right)$

\begin{tabular}{crrrr}
\hline Model & \multicolumn{1}{l}{ R } & R Square & $\begin{array}{l}\text { Model Summary } \\
\text { Adjusted R Square }\end{array}$ & Std. Error of the Estimate \\
\hline 1 &, $502^{\mathrm{a}}$ &, 252 &, 205 &, 93519
\end{tabular}

a. Predictors: (Constant), X2, X1

Sumber: Data olah SPSS

Analisis regresi linear berganda mengamati goodness of fit (uji kecocokan) dengan melihat adjusted $\mathrm{R}$ square. Nilai adjusted $\mathrm{R}$ square $=0,205$ artinya bahwa $20,5 \%$ variabel tingkat kepatuhan pajak berdasarkan reporting compliance dapat dijelaskan oleh variasi dari kedua variabel independen yaitu orientasi pasar dan bentuk perusahaan. Sedangkan sisanya $(100 \%-20,5 \%=79,5 \%)$ dijelaskan oleh sebab-sebab lain di luar model.

\section{Uji Hipotesis}

Tabel 5 Uji Signifikan Simultan Uji F

\begin{tabular}{|c|c|c|c|c|c|c|}
\hline \multicolumn{7}{|c|}{ ANOVA $^{\mathrm{a}}$} \\
\hline & & Sum of Squares & $\mathrm{df}$ & Mean Square & $\mathrm{F}$ & Sig. \\
\hline \multirow{3}{*}{1} & Regression & 9,428 & 2 & 4,714 & 5,390 &, $010^{\mathrm{b}}$ \\
\hline & Residual & 27,987 & 32 & 875 & & \\
\hline & Total & 37,415 & 34 & & & \\
\hline \multicolumn{7}{|c|}{ a. Dependent Variable: LG10_RS } \\
\hline \multicolumn{7}{|c|}{ b. Predictors: (Constant), X2, X1 } \\
\hline
\end{tabular}


Uji $F$ (F-test) pada tabel di atas, didapat nilai $F_{\text {hitung }}$ sebesar 5,390 dengan nilai signifikansi 0,010. Karena nilai signifikansi jauh lebih kecil dari $\alpha=0,05$, maka dapat disimpulkan bahwa orientasi pasar dan bentuk perusahaan perusahaan secara bersama-sama memiliki pengaruh terhadap tingkat kepatuhan pajak berdasarkan reporting compliance.

Tabel 6 Uji Statistik t

\begin{tabular}{|c|c|c|c|c|c|c|}
\hline \multirow{2}{*}{\multicolumn{2}{|c|}{ Model }} & \multicolumn{2}{|c|}{$\begin{array}{l}\text { Unstandardized } \\
\text { Coefficients }\end{array}$} & \multirow{2}{*}{$\begin{array}{c}\text { Standardized Coefficients } \\
\text { Beta }\end{array}$} & \multirow[t]{2}{*}{$\mathbf{t}$} & \multirow[t]{2}{*}{ Sig. } \\
\hline & & B & Std. Error & & & \\
\hline & (Constant) & $-3,594$ & ,680 & & $-5,283$ & , 000 \\
\hline 1 & $\mathrm{X} 1$ & 2,192 & ,681 & ,492 & 3,216 & ,003 \\
\hline & $\mathrm{X} 2$ &,- 175 & ,320 &,- 084 &,- 547 & ,588 \\
\hline
\end{tabular}

Berdasarkan koefisien yang telah diperoleh pada tabel di atas, maka persamaan regresi linier berganda adalah sebagai berikut:

$\log 10(\mathrm{RS})=-3,594+2,192 \mathrm{OP}-0,175 \mathrm{SB}$

Dimana:

Log10 (RS) = Tingkat Ketidakpatuhan berdasarkan Reporting Compliance

$\mathrm{OP} \quad=$ Variabel $\mathrm{X}_{1}$ yaitu orientasi pasar

$\mathrm{SB} \quad=$ Variabel $\mathrm{X}_{2}$ yaitu bentuk perusahaan

Hasil penelitian menunjukkan bahwa orientasi pasar (X1) diperoleh $t_{\text {hitung }}$ sebesar 3,216 dengan signifikansi sebesar 0,003 maka variabel orientasi pasar (X1) berpengaruh signifikan terhadap tingkat ketidakpatuhan pajak berdasarkan reporting compliance. Sedangkan variabel bebas lainnya seperti bentuk perusahaan (X2) tidak berpengaruh signifikan terhadap tingkat ketidakpatuhan pajak berdasarkan reporting compliance. Hal ini dikarenakan $t_{h i t u n g}$ bentuk perusahaan (X2) sebesar -0,547 dengan signifikansi sebesar 0,588 maka $\mathrm{H}_{\mathrm{o}}$ diterima dan $\mathrm{H}_{\mathrm{a}}$ ditolak pada level of significant sebesar 0,05 .

\section{Pembahasan}

Pada bagian ini akan dibahas temuan penelitian atas analisis data empiris sehubungan dengan hipotesis yang diajukan.

\section{Pengaruh Orientasi Pasar terhadap Tingkat Kepatuhan Wajib Pajak Badan berdasarkan Pengukuran Reporting Compliance}

Berdasarkan hasil uji $t$, nilai $t_{\text {hitung }}$ lebih besar dari $t_{\text {tabel }}$, yaitu 3,216>2,037 dan koefisien yang bernilai positif sebesar 2,192 dengan nilai signifikansi di bawah 0.05 yaitu 0,003 yang berarti signifikan. Pada hasil regresi variabel orientasi pasar memiliki koefisien 2,192 yang mengandung pengertian bahwa variabel orientasi pasar memiliki pengaruh positif terhadap tingkat ketidakpatuhan pajak (dikarenakan pengukuran variabel dependen menggunakan koreksi pemeriksaan pajak, dimana semakin tinggi persentase koreksi semakin tidak patuh 
wajib pajak. Sehingga dengan menetapkan nilai variabel dummy 0 (nol) untuk kategori orientasi pasar ekspor dan 1 (satu) untuk kategori orientasi pasar lokal (domestic), perusahaan dengan orientasi pasar lokal (domestic) memiliki tingkat ketidakpatuhan yang lebih tinggi dibandingkan dengan perusahaan dengan orientasi pasar ekspor. Dengan kata lain, perusahaan yang berorientasi pasar ekspor (dummy nilai 0) memiliki tingkat kepatuhan yang lebih tinggi dibandingkan dengan perusahaan yang berorientasi pasar lokal/domestic (dummy nilai 1), atau variabel orientasi pasar memiliki pengaruh negatif dan signifikan terhadap tingkat kepatuhan pajak. Hipotesis pertama diterima.

Perusahaan orientasi pasar ekspor memiliki tingkat kepatuhan lebih tinggi dibandingkan dengan perusahaan berorientasi pasar lokal (domestic) dikarenakan terdapat insentif tarif Pajak Pertambahan Nilai (PPN) 0\% dikenakan untuk penjualan produk ke luar negeri atau ekspor. Temuan ini sesuai dengan hasil penelitian Chan dan Mo (2002). Selain itu, perusahaan berorientasi pasar ekspor bertujuan untuk mendapatkan status wajib pajak patuh. Berdasarkan PMK No.198/PMK.03/2013 tentang Pengembalian Pendahuluan Kelebihan Pembayaran Pajak, salah satu syarat wajib pajak patuh adalah kebenaran penulisan dan penghitungan pajak. Perusahaan berorientasi pasar ekspor cenderung memiliki pajak masukan lebih banyak dibandingkan dengan pajak keluarannya, dikarenakan PPN Keluarannya adalah PPN 0\%.

Berdasarkan PMK No. 16/PMK.03/2013 tentang Rincian Jenis Data dan Informasi serta Penyampaian Data dan Informasi yang Berkaitan dengan Perpajakan, bahwa salah satu instansi yang telah diwajibkan untuk memberikan data dan informasi perpajakan kepada DJP adalah Direktorat Jenderal Bea dan Cukai. Oleh karena itu, terdapat keterkaitan data terkait penjualan ekspor yang ada di Direktorat Jenderal Pajak (DJP) dengan data yang dimiliki Direktorat Jenderal Bea Cukai (DJBC) sehingga resiko terdeteksinya tinggi jika perusahaan melakukan ketidakpatuhan pelaporan terkait omset atau peredaran bruto yang dilaporkan.

Sedangkan perusahaan berorientasi pasar lokal (domestic) lebih tidak patuh dalam pelaporannya karena berdasarkan data penelitian terdapat underreporting penghasilan dan overreporting biaya pengurang penghasilan. Hal ini sesuai dengan Risk Aversion Theory yang dikemukakan oleh Allingham and Sandmo (1972) bahwa tidak ada individu bersedia membayar pajak secara sukarela (voluntary compliance) individu akan selalu menentang untuk membayar pajak (risk aversion). Penjualan dalam negeri dikenakan tarif PPN, dengan demikian perusahaan cenderung tidak melaporkan seluruh penjualannya. Selain itu terdapat overreporting biaya fiskal. Biaya lain-lain merupakan biaya yang paling rentan dalam perusahaan berorientasi pasar lokal (domestic) seperti biaya entertain, dan lain-lain. Biaya untuk "memperlancar urusan" seperti mengentertain pelanggan dan supplier utama biasanya diklasifikasikan pada biaya lainlain, dan dijadikan sebagai deductible expense. Untuk mendeteksi ketidakpatuhan pelaporan tersebut, biaya lain-lain tersebut dipilah-pilah dan ditelusuri kembali oleh pemeriksa pajak. Jika tidak terdapat dokumen bukti pendukung yang membuktikan bahwa biaya tersebut merupakan biaya pengurang penghasilan berdasarkan UU No. 36 Tahun 2008, biaya tersebut langsung diklasifikasikan sebagai non deductible expense. Inilah yang mengakibatkan terdapat penghasilan 
neto hasil pemeriksaan fiskus lebih besar dibandingkan dengan penghasilan neto menurut laporan wajib pajak badan.

\section{Pengaruh Bentuk Perusahaan terhadap Tingkat Kepatuhan Wajib Pajak Badan berdasarkan Pengukuran Reporting Compliance}

Berdasarkan hasil pengujian statistik $t$, nilai $t_{\text {hitung }}$ lebih kecil dari $t_{\text {tabel }}$, yaitu $-0,547<2,037$ dengan nilai signifikansi di atas 0.05 yaitu 0,588 yang berarti tidak signifikan. Hal ini mengindikasikan bahwa bentuk perusahaan tidak berpengaruh signifikan terhadap tingkat kepatuhan Wajib Pajak Badan berdasarkan pengukuran reporting compliance. Hipotesis kedua ditolak.

Hipotesis penelitian menyatakan bahwa bentuk perusahaan PT lebih patuh dalam hal kepatuhan pelaporannya dibandingkan dengan perusahaan selain PT, dikarenakan memiliki keterlibatan pemilik minimal, usaha dijalankan oleh manajemen, perusahaan lebih terstruktur, terdapat sistem pengendalian yang lebih terkontrol, serta mempunyai pertanggungjawaban yang ketat terhadap pemilik, sehingga manajemen lebih sulit melakukan rekayasa pembukuan dan laporan keuangan. Namun, hal tersebut rupanya tidak cukup menjadi insentif bagi bentuk perusahaan PT agar bertindak lebih patuh dibandingkan dengan perusahaan selain PT. Ternyata pada perusahaan yang tidak patuh hal tersebut hanya berlaku pada pembuatan laporan keuangan komersialnya. Berbeda perlakuannya dalam pembuatan laporan keuangan fiskal. Hal ini dikarenakan pada dasarnya manajemen dan pemilik memiliki kepentingan yang sama, yaitu mengecilkan pajak terutang perusahaan. Kepentingan manajemen mengecilkan pajak terutang adalah mengecilkan beban, yaitu beban pajak, agar mencapai efisiensi usaha, likuiditas perusahaan tidak terganggu, mendapatkan insentif, serta memanfaatkan kas untuk kepentingan lain seperti opportunity cost. Sedangkan kepentingan pemilik atau pemegang saham dalam mengecilkan pajak terutang adalah memaksimalkan dividen. Pada umumnya pemilik atau pemegang saham berorientasi pada laba, karena laba perusahaan yang dihasilkan berkaitan dengan deviden yang dibagikan kepada pemegang saham. Persamaan kepentingan antara manajemen dan pemegang saham tersebut sesuai dengan teori akuntansi positif (positive accounting theory) yang dikemukakan oleh Watts dan Zimmerman (1986). Berdasarkan teori ini perusahaan yang lebih besar akan lebih sensitif terhadap biaya pajak dan menggunakan metode akuntansi yang mengurangi laba bersih laporan keuangan. Oleh karena itu, perusahaan berbentuk PT dapat bertindak tidak patuh dibandingkan dengan perusahaan selain PT (seperti: CV, Firma, dll), sehingga hipotesis kedua dalam penelitian ini ditolak.

Di samping itu, bentuk perusahaan tidak berpengaruh signifikan terhadap tingkat kepatuhan berdasarkan pengukuran reporting compliance dikarenakan baik perusahaan yang berbentuk PT maupun selain PT dapat lebih patuh maupun tidak patuh. Sehingga terdapat empat kemungkinan yang bisa terjadi diantaranya yaitu: bentuk perusahaan PT dapat bertindak patuh maupun tidak patuh, dan bentuk perusahaan selain PT juga dapat bertindak patuh maupun tidak patuh.

Perusahaan PT dapat lebih patuh daripada bentuk perusahaan selain PT karena bentuk perusahaan PT memiliki tingkat kerumitan yang lebih tinggi, sehingga lebih membutuhkan pembukuan yang lebih lengkap dan teratur. Dengan demikian terdapat dokumen bukti pendukung yang lebih lengkap agar tidak terjadi koreksi pemeriksaan jika terjadi pemeriksaan pajak sewaktu-waktu. Berdasarkan 
Teori Besaran (Size) Organisasi yang dikemukakan oleh kelompok Aston, organisasi yang lebih besar akan mempunyai lebih banyak peraturan yang bersifat formal. Pada perusahaan berbentuk PT, penggunaan peraturan yang bersifat formal misalnya sistem pengendalian internal. Manajemen perusahaan diwajibkan membuat dan memelihara sistem pengendalian internal yang memadai. Dalam hal penyediaan informasi keuangan, pihak manajemen bertanggung jawab untuk memberikan jaminan bagi pemegang saham bahwa perusahaan telah dikendalikan dengan baik. Dengan adanya pengendalian yang ketat tersebut, manajemen lebih sulit memanipulasi laporan keuangan yang dapat digunakan sebagai dasar untuk penghitungan pajak. Dengan demikian, dikarenakan perusahaan berbentuk PT lebih formal dan ketat dalam hal pengawasan dan penggunaan peraturannya, perusahaan berbentuk PT dapat memiliki tingkat kepatuhan yang lebih tinggi dalam kepatuhan pelaporannya dibandingkan dengan perusahaan selain PT $(\mathrm{CV}$, Firma, dll). Selain itu, bentuk perusahaan PT dapat lebih patuh karena pada umumnya memiliki konsultan pajak sendiri sehingga pengetahuan terkait perpajakan tinggi. Hal ini menghindarkan perusahaan dari kesalahan pelaporan akibat kurangnya pemahaman undang-undang perpajakan.

Namun seperti yang dijelaskan sebelumnya, hal tersebut rupanya tidak cukup menjadi insentif bagi bentuk perusahaan PT agar bertindak lebih patuh dibandingkan dengan perusahaan selain PT. Hal ini dikarenakan meskipun bentuk perusahaan PT keterlibatan pemiliknya minimal, usaha dijalankan oleh manajemen, perusahaan lebih terstruktur, terdapat sistem pengendalian yang lebih terkontrol, serta mempunyai pertanggungjawaban yang ketat terhadap pemilik sehingga manajemen lebih sulit melakukan rekayasa pembukuan dan laporan keuangan, ternyata pada perusahaan yang tidak patuh hal tersebut hanya berlaku pada pembuatan laporan keuangan komersialnya. Berbeda perlakuannya dalam pembuatan laporan keuangan fiskal. Hal tersebut disebabkan karena pada dasarnya manajemen dan pemilik memiliki kepentingan yang sama, yaitu mengecilkan pajak terutang perusahaan. Selain itu, bentuk perusahaan PT biasanya dijalankan oleh sumber daya manusia yang lebih kompeten dan memiliki pengetahuan perpajakan yang lebih tinggi, sehingga kemampuan avoidance tax atau penghindaran pajak pada bentuk perusahaan PT lebih tinggi dibandingkan dengan perusahaan berbentuk selain PT. Berdasarkan Risk Averison Theory, Declared Income atau penghasilan yang dilaporkan bergantung pada perilaku individu terhadap risiko. Bentuk perusahaan PT lebih risk taker dalam pengambilan keputusannya. Perilaku pengambilan keputusan oleh organisasi menentukan sejauh mana tingkat kemungkinan kecurangan dapat terdeteksi (probability of detection), dan seringkali bersifat subyektif. Dalam hal ini perusahaan akan memilih declared income untuk memaksimalkan utilitas yang diharapkannya atas tindakan spekulasi dari penghindarannya (evasion gamble).

Hasil penelitian pada pengujian pengaruh parsial menerima hipotesis nol yang berarti tidak signifikan tersebut membuktikan bahwa bentuk perusahaan selain PT dapat bertindak lebih patuh atau tidak patuh dalam pemenuhan perpajakannya. Seperti yang diduga sebelumnya, bentuk perusahaan selain PT lebih tidak patuh karena memiliki keterlibatan yang besar dari pemilik. Manajemen sehari-hari biasanya dilakukan oleh pemilik sendiri atau orang kepercayaan dari pemilik itu sendiri. Berdasarkan Teori Besaran (Size) Organisasi 
yang dikemukakan oleh kelompok Aston, perilaku organisasi (seperti: manajer dan karyawan) pada perusahaan besar lebih formal dibandingkan dengan perusahaan kecil. Dalam teori ini organisasi yang lebih kecil akan mempunyai lebih sedikit peraturan. Dengan demikian perusahaan berbentuk selain PT memiliki pengendalian yang kurang ketat dibandingkan dengan perusahaan berbentuk PT. Skala usaha yang kecil-menengah dengan sifat usaha yang cukup sederhana, pembukuan biasanya dilakukan secara sederhana, dan lebih tidak terkontrol jika dibandingkan PT, bentuk perusahaan selain PT lebih mudah dalam pemanipulasian laporan keuangan dibandingkan dengan perusahaan berbentuk PT.

Pembukuan bentuk perusahaan selain PT pada umumnya dilakukan secara sederhana sehingga jika tiba-tiba terjadi pemeriksaan pajak biasanya terdapat bukti pendukung yang kurang lengkap. Hal ini menyebabkan terjadinya koreksi pemeriksaan yang mengakibatkan penghasilan neto lebih besar dari yang dilaporkan sebelumnya. Selain itu, kurangnya pengetahuan perpajakan pada sumber daya manusia yang mengelola bentuk perusahaan selain PT, mengakibatkan adanya underreporting penghasilan neto perusahaan.

Di sisi lain, perusahaan berbentuk selain PT seperti: CV, Firma, dll, juga dapat lebih patuh dibandingkan dengan perusahaan berbentuk PT. Berdasarkan teori akuntansi positif (positive accounting theory) yang dikemukakan oleh Watts dan Zimmerman (1986), menyatakan bahwa jika perusahaan yang lebih besar akan lebih sensitif terhadap biaya pajak dan menggunakan metode akuntansi yang mengurangi laba bersih laporan keuangan, namun hal ini terjadi sebaliknya pada perusahaan berukuran kecil yang berupaya menampilkan laba yang lebih baik. Perusahaan berbentuk selain PT dapat lebih patuh karena memiliki kemampuan menghindari pajak yang rendah atau avoidance tax lebih rendah dibandingkan dengan perusahaan berbentuk PT. Berdasarkan Risk Aversion Theory bahwa Declared Income bergantung pada perilaku individu terhadap risiko. Perusahaan berbentuk selain PT biasanya kurang berani mengambil resiko tinggi untuk memanipulasi laporan keuangan fiskalnya. Sehingga perusahaan berbentuk selain PT dapat cenderung lebih patuh dalam pemenuhan pelaporan perpajakannya.

\section{SIMPULAN}

Berdasarkan hasil pengujian yang penulis lakukan dalam penelitian ini, dapat disimpulkan bahwa: (1) Orientasi Pasar berpengaruh secara signifikan terhadap tingkat kepatuhan Wajib Pajak Badan berdasarkan pengukuran reporting compliance. (2) Bentuk Perusahaan tidak berpengaruh secara signifikan terhadap tingkat kepatuhan Wajib Pajak Badan berdasarkan pengukuran reporting compliance. 


\section{DAFTAR PUSTAKA}

Allingham M. G. and A. Sandmo. 1972. "Income Tax Evasion: A Theoretical Analysis". Journal of Public Economics. 1 (3/4) pp. 323-340.

Brown, Robert E. and Mazur, Mark J. 2003. "IRS s Comprehensive Approach to Compliance Measurement". National Tax Journal. 61 : 689-99.

Chan, K. H. and P. L. L. Mo. 2002. "The Impact of Firm Characteristics on BookTax-Conforming and Book-Tax-Difference Audit Adjustments". The Journal of the American Taxation Association. Vol. 24, No. 2, pp. 18-34.

Fry, Fred L., Charles R. Stoner, dan Richard E. Hattwick. 2001. Business : an Integrative Approach, second edition. McGraw-Hill, International Edition.

Gujarati, Damodar. 1995. Ekonometrika Dasar. Jakarta: Penerbit Erlangga.

Gunadi. 2005. Indonesian Taxation; A Reference Guide. Jakarta: Multi Utama Publishing.

Hani, Syafrida dan Lubis, Muhammad Rizal. 2010. "Pengaruh Karakteristik Perusahaan Terhadap Kepatuhan Wajib Pajak". Jurnal Riset Akuntansi dan Bisnis. Vol. 10 No. 1 Maret 2010. 
Internal Revenue Service - United States Department of The Treasury. 2005. "New IRS Study Provides Preliminary Tax Gap Estimate". IR-2005-38, www.irs.gov/newsroom/article.

James dan Alley. 1999. "Tax Compliance, Self Assessment and tax Administration". Journal of Finance and Management in Public Service. Volume 2 Number 2.

J. Kasipillai, HA Jabbar. 2006. "Income tax non-compliance of small and medium enterprises in Malaysia: determinants and tax compliance costs". Asian Academy of Management Journal. 11 (2), 73-88, 2006. 15, 2006.

Kusumaningtias, Rohmawati dan Satyawan, Made Dudy (Ed.). 2011. Aspek Hukum Dalam Bisnis. Surabaya: Unesa University Press.

Mardiasmo. 2009. Perpajakan, Edisi Revisi 2009. Yogyakarta: Penerbit Andi.

Organisation For Economic Co-Operation and Development (OECD). 2004. "Compliance Risk Management: Managing and Improving Tax Compliance". Dalam Centre For Tax Policy and Administration. Committee on Fiscal Affairs October 2004.

Peraturan Menteri Keuangan Nomor 16/PMK.03/2013 tentang Rincian Jenis Data dan Informasi serta Penyampaian Data dan Informasi yang Berkaitan dengan Perpajakan

Peraturan Menteri Keuangan Nomor 17/PMK.03/2013 tentang Tata Cara Pemeriksaan.

Peraturan Menteri Keuangan Nomor 198/PMK.03/2013 tentang Pengembalian Pendahuluan Kelebihan Pembayaran Pajak

Purnomo, Hadi. 2004. "DJP Menjadi Ujung Tombak Reformasi”. Dalam Majalah Berita Pajak. No. 1514/Tahun XXXV/1 Mei 2004.

Robbins, Stephen P. 1994. Teori Organisasi: Struktur, Desain dan Aplikasi. Edisi Tiga. Bandung: Penerbit Arcan

Segara, Fuad Bambang. 2006. Pengaruh Karakteristik Usaha Wajib Pajak Badan terhadap Tingkat Kepatuhan dalam Pemenuhan Kewajiban Pajak Penghasilan Berdasarkan Pendekatan Reporting Compliance. Tesis tidak diterbitkan. Surabaya: PPs Universitas Airlangga.

Suryadi. 2006. "Model Hubungan Kausal Kesadaran, Pelayanan, Kepatuhan Wajib Pajak dan Pengaruhnya terhadap Kinerja Penerimaan Pajak; Suatu Survey di Wilayah Jawa Timur". Jurnal Keuangan Publik. Volume 4 No.1 April 2006.

Undang-undang Republik Indonesia No. 1 Tahun 1995 tentang Perseroan Terbatas.

Undang-undang Republik Indonesia Nomor 28 Tahun 2007 tentang Ketentuan Umum Perpajakan.

Undang-undang Republik Indonesia Nomor 36 Tahun 2008 tentang Pajak Penghasilan.

Waluyo. 2010. "Pengaruh Karakteristik Individu Wajib Pajak, Karakteristik Perusahaan dan Struktur Kepemilikan Terhadap Tingkat Kepatuhan Pajak". Jurnal Akuntansi. Tahun XIV, No. 01, Januari 2010: 98-112.

Watts, R. L. dan Zimmerman, J. L. 1986. Positive Accounting Theory. New Jersey: Printice-Hall International Inc. 
2013. Suplemen Pajak 2013: Penegakan Hukum Amankan Lumbung Negara. Jakarta: Direktorat Jenderal Pajak. 